\author{
Grzegorz Stencel \\ Mgr inż. \\ Instytut Kolejnictwa \\ gstencel@ikolej.pl
}

\title{
Study of lateral wear of needles in railway switches
}

\begin{abstract}
The article concerns the problems of wear of switch blades in switches. On the basis of observations and measurements, factors favoring lateral wear were determined. The measurements which are made when examining the lateral wear of the switch blades were determined. The practical example shows the method of indicating the causes of lateral wear of the switch blades, taking into account the dependence between the hardness of the needles and lateral wear. The methods of preventing the excessive wear of switch blades have been mentioned.
\end{abstract}

Keywords: Switch blade; Wear; Switches

\section{Introduction}

The lateral wear of the needles is a known phenomenon occurring in railway switches. Due to the geometry of turnouts, the natural occurrence of lateral wear is arched needles, although, for various reasons (e.g. narrowing of the main track), this phenomenon may also occur in straight needles. In turnouts with smaller radii $(190$ or $300 \mathrm{~m})$, lateral wear of the arc needles develops much faster due to the greater angle of vehicle wheels.

\section{Factors conducive to lateral wear of the needles}

It is natural that turnouts more loaded with vehicle traffic will be intuitively indicated as more strongly threatened by excessive wear of the needles. However, there are many pitfalls in such a general thesis. First of all, it is not easy to define and determine the traffic load indicator. In most analyzes, we use the value of the cumulative load expressed in Tg. Apart from difficulties or time-consuming for precise determination of such index for the return path in a given junction, one should also be aware that e.g. in the context of diagnosing causes of excessive lateral wear of the needles, the load value expressed in $\mathrm{Tg}$ is not a complete description of the traffic load, because the same the value of $20 \mathrm{Tg}$ resulting from the movement of vehicles with elastic (susceptible) suspension will result in other phenomena in the surface than $20 \mathrm{Tg}$ transferred as a result of the movement of vehicles with rigid suspension. In addition, in the composition of freight trains, there are more and more often two locomotives, so their share in the transferred load is bigger than it used to be.

Among the factors conducive to the occurrence of the phenomenon of lateral wear described in the article, one can distinguish both those concerning the turnout itself, as well as those relating to vehicles that are traveling after a given journey. Due to the complexity and difficulty in parameterizing these factors, discussions about the causes of wear of rails and wheels of vehicles can arouse great emotions and are the subject of many disputes [1]. Factors related to vehicles are usually not attributable to wear on a specific trip (unless we consider a case of a separate infrastructure such as a metro), therefore the article focuses on the factors concerning turnouts only, but it must be stressed that both groups of factors can largely decide the size of lateral wear of needles and rails. 


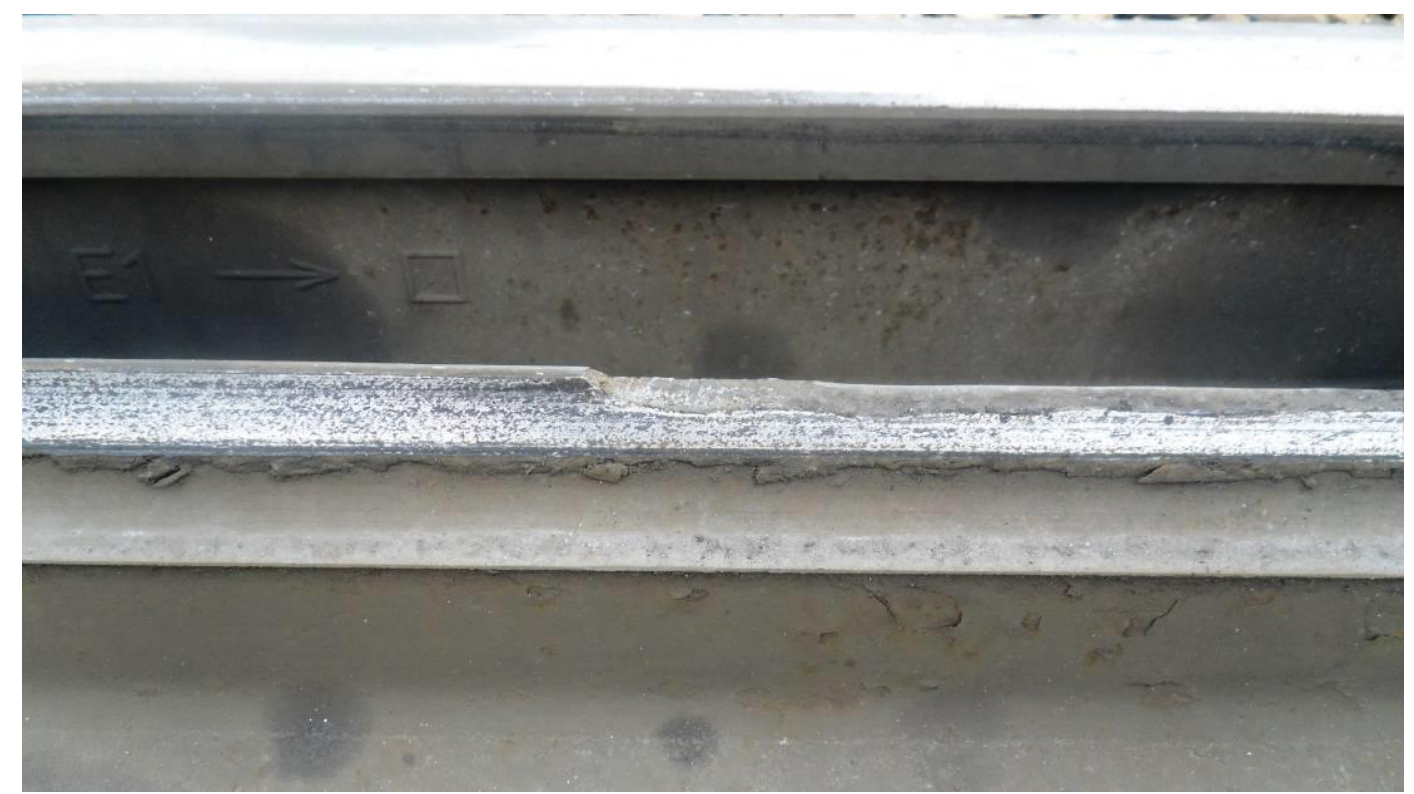

1. The chipping of the worn needle

Factors which have their source in vehicles that are conducive to the wear of the needles are broadly understood imperfections of driving systems, which include excessive suspension stiffness, geometrical imperfections of wheel profiles and wheelsets as well as other defects that are often detected only after the occurrence of an event, e.g. improperly maintained pivots in freight wagons. In switches, we can distinguish a number of geometrical parameters on the basis of which it can be stated that there are circumstances favorable to lateral wear. These include track width, gradient, canting, twisted. Due to limited hardware and personnel capabilities, these parameters are uncommonly recorded using self-recording rail gauges enabling measurement every $0.5 \mathrm{~m}$ or with even more frequent sampling. From the charts made on the basis of such measurements, many more conclusions can be drawn than in the case of measurements made with the use of traditional hand-held gauges.

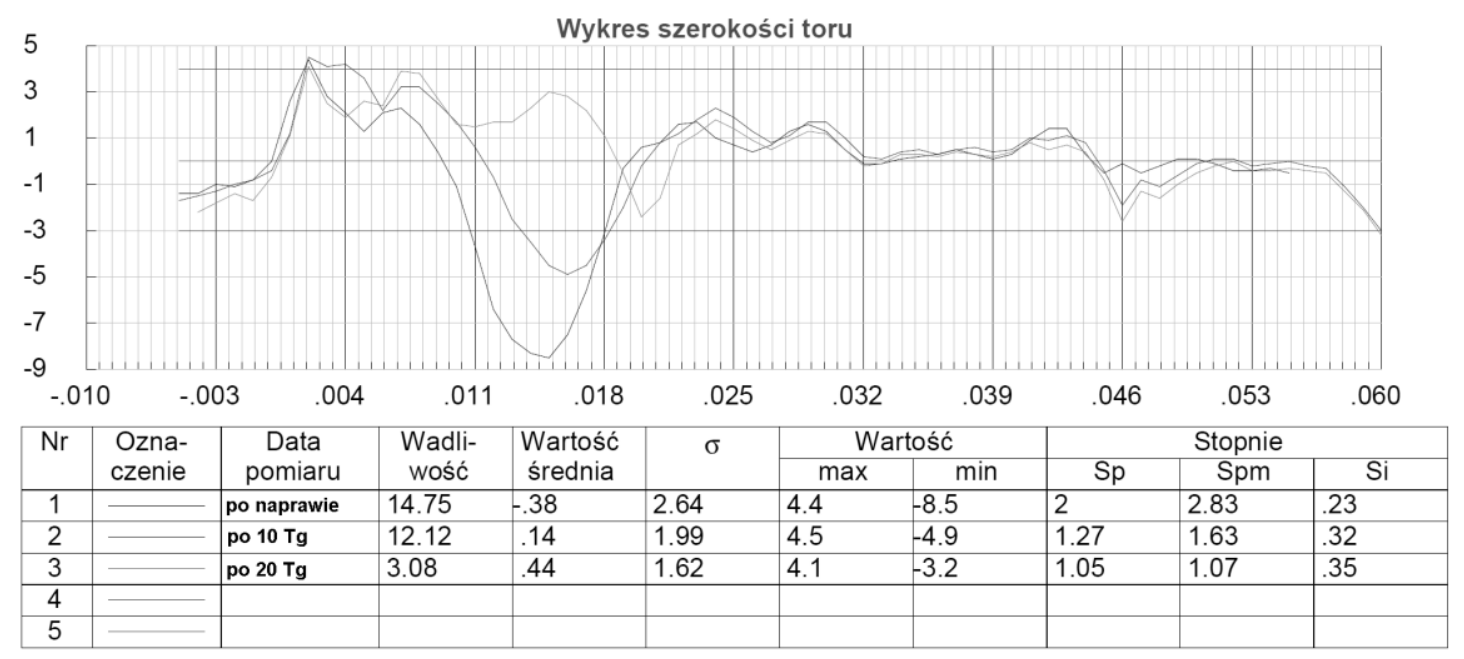

2. The graph of the straight track width in the switch

Figure 1 shows the superimposed diagrams from the measurement of straight track in the switch, made after installation and after 10 and $20 \mathrm{Tg}$. Visible narrowing of the track at the beginning of the operation (more than $8 \mathrm{~mm}$ in value) is visible, which can affect the excessive lateral wear of the needles. In the case of measurements with a traditional torch of 
this type, the fault may be overlooked. Narrowing of this value may result from inaccuracies in the assembly of the turnout before installation (which also occurs on prestressed concrete sleepers [3]) or is caused by the deformation of the needles, e.g. due to improperly adjusted under-pile rolls. Another parameter that may have an impact on excessive wear are increased values of cant and twist, as a result of which there may be an uneven load on the rail tracks, including the load on the external course affecting the increased wear of the needles and rails. As with the track gauge parameter, it is also recommended to measure the twist and cantilever using a self-recording torch.

\section{Study of lateral wear of the needles}

The lateral wear of the needles can be measured with a vernier caliper (figure 3) or an electronic profilometer (figure 4).

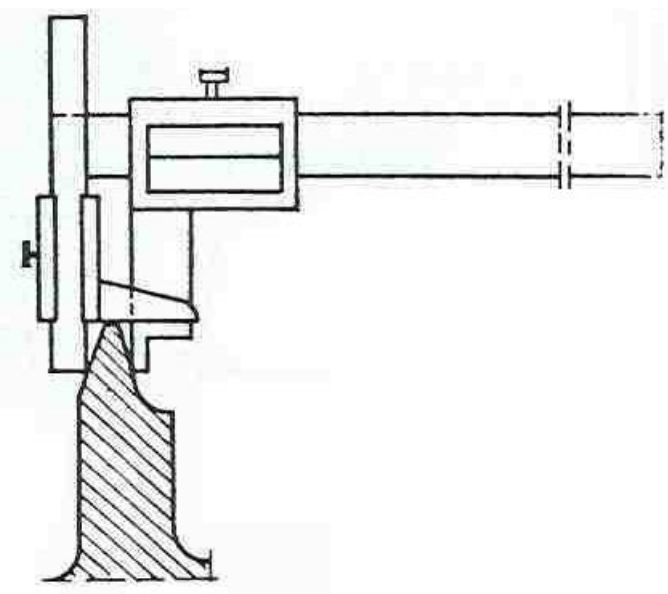

3. Measurement of the needle with a slide gauge

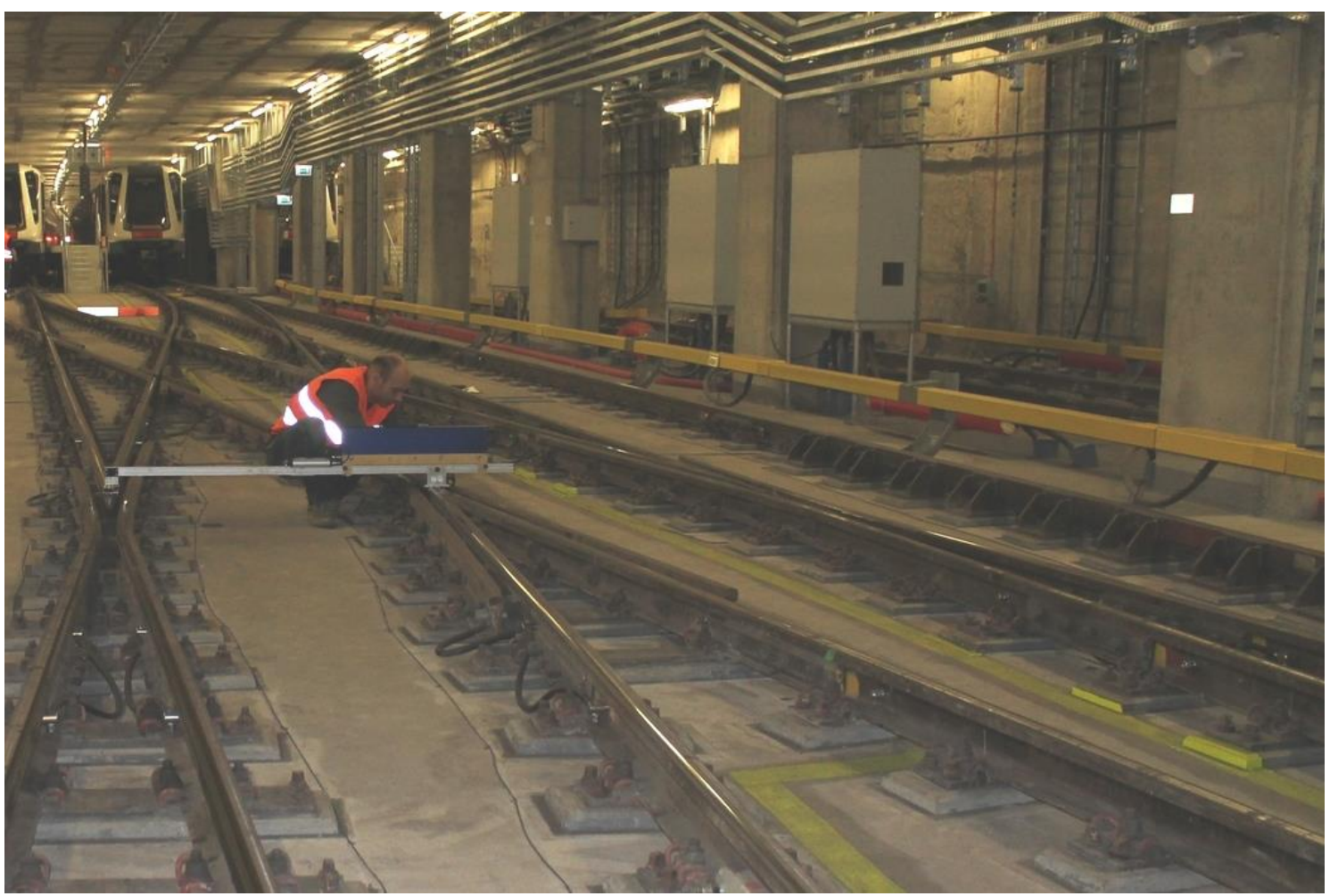

4. Measurement with electronic profilometer 
Measurements are usually made in several selected cross-sections along the length of the needle, e.g. every $2 \mathrm{~m}$. The number of lateral needles can be determined with more accuracy if measurements were taken before starting operation, but usually, no such measurements are available, so the result of the worn profile measurement should be referred to the theoretical shape of the nominal spire in a given cross-section.

In determining the causes of excessive needle wear, in addition to measurements of lateral wear and geometric parameters of the switch, the hardness of the steel from which the sections were made should also be checked. This measurement is carried out with portable devices, the accuracy of which is usually $\pm 10 \%$. It is not possible, on the basis of such measurements, to assess the compliance of the needles with the requirements of the standard, but they are helpful in determining the possible causes of excessive wear.

\section{An example of determining the causes of excessive lateral wear}

Research on the reasons for the wear of the needles at one of the stations was carried out in turnouts with a radius of $500 \mathrm{~m}$, in which needles made of R260 steel were used. Measurement of lateral wear was carried out every $2 \mathrm{~m}$. The highest values of wear were recorded in sections 2 and $4 \mathrm{~m}$ from the needle point.

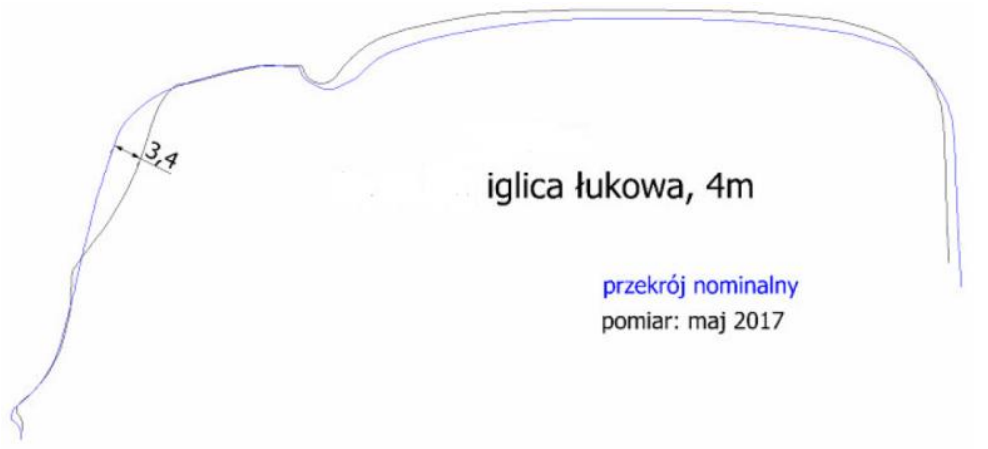

5. Wear of the arc needle

The switch, in which the largest lateral wear in the arched needles $(3.4 \mathrm{~mm})$ was recorded, was a switch built in the main track (Figure 5). In the turning direction of the turnout, the entire freight train traffic took place at the station, as it led to a group of freight tracks. It was estimated that the cumulative load accumulated in the turning direction of this turnout was about $20 \mathrm{Tg}$. Experience from other measurements indicates that at this load value, the lateral wear of arc needles (R260 grade steel) of $4 \mathrm{~mm}$ is not an anomaly. When using such a value, there are often nicks in the spikes (Figure 1). The measurement of hardness of the arched needle was also carried out in the switch; the values were over $260 \mathrm{HB}$.

The study also examined the lateral wear of the needles in three pairs of turnouts located in the connections of the main tracks (for the purposes of the article, number of switches: 1 and 2, 3 and 4 and 5 and 6. The dependence between the hardness of the needles and lateral wear when comparing individual pairs of turnouts:

- in turn No. 1 in the arc needle (2. m), wear was $1.64 \mathrm{~mm}$ and the hardness was $234 \mathrm{HB}$, while in the No. 2, consumption was $1.1 \mathrm{~mm}$ and the hardness was $268 \mathrm{HB}$,

- in turn No. 3 in the arc needle (2. m) there was a wear of $2.25 \mathrm{~mm}$ and a hardness of 216 $\mathrm{HB}$, while in the No. 4 there was a wear of $0.86 \mathrm{~mm}$ and a hardness of $247 \mathrm{HB}$,

- in turn No. 5 in the arc needle (2. m) there was $1.61 \mathrm{~mm}$ wear and $232 \mathrm{HB}$ hardness, while in the No. 6, the consumption was $0.21 \mathrm{~mm}$ and the hardness was $281 \mathrm{HB}$.

Such dependence has already been noticed when measurements were made a few years earlier at another station, where the needles of steel R260 were used in the connection of tracks in 
one of the switches, and in the second - steel R350HT. The wear of the harder needles was half the size [2].

\section{Summary}

During the modernization of railway lines, due to the fact that there is traffic on one track, turnouts are often operated in reverse directions. As a result of such exploitation, lateral wear of steel elements with values greater than those expected by the infrastructure manager arises. Arc needles are the most exposed to wear and damage.

The tests showed a clear relationship between the lateral wear and the value of the hardness of the needles. The use of cured steel needles should therefore be considered highly justified. The aim of alleviating the effects of the wear phenomenon is also required to grind turnouts both in the initial mode, thanks to which the occurrence of defects is limited [1], as well as in the preventive mode to remove runoffs. In recent years, many solutions have been implemented on the Polish rail network, which are conducive to reducing the occurrence of lateral wear of the needles. These include the widespread use of track lubricators, as well as an increase in the number of turnouts with needles made of hardened steel, or the improvement of the geometric quality of switches by deliveries in blocks.

\section{Source materials}

[1] Mikłaszewicz I.: Odwęglenie a wady powierzchni główki szyny. Problemy Kolejnictwa, 2015, Zeszyt numer 165, s. 85-96;

[2] Stencel G.: Nowe wyzwania dla projektantów w zakresie doboru składników nawierzchni kolejowej $\mathrm{z}$ uwagi na jej trwałość. Materiały konferencyjne IV Konferencji Naukowo-Technicznej: „Projektowanie, budowa i utrzymanie infrastruktury w transporcie szynowym - INFRASZYN 2011". Zakopane, 68.04.2011;

[3] Stencel G.: Ocena jakości geometrycznej torów i rozjazdów na zmodernizowanych liniach kolejowych. Zeszyty Naukowo-Techniczne Oddziału Stowarzyszenia Inżynierów i Techników Komunikacji RP w Krakowie. Seria: Materiały Konferencyjne, Nr 3(99)/2012. Kraków 2012;

[4] Urbanowicz W.: Problem Metra z kołami Inspiro. Trzykrotny wzrost zużycia szyn. Portal internetowy www.transport-publiczny.pl, ostatni dostęp: 27.12.2017. 